Supplement of The Cryosphere, 12, 3409-3418, 2018

https://doi.org/10.5194/tc-12-3409-2018-supplement

(c) Author(s) 2018. This work is distributed under

the Creative Commons Attribution 4.0 License.

(c) (1)

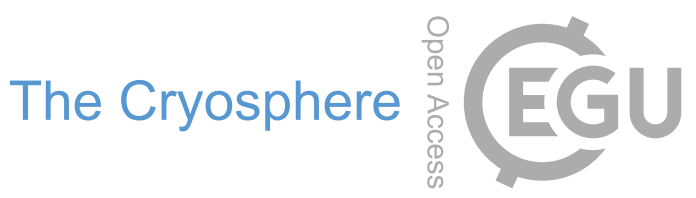

Supplement of

\title{
Brief communication: Impact of the recent atmospheric circulation change in summer on the future surface mass balance of the Greenland Ice Sheet
}

A. Delhasse et al.

Correspondence to: Alison Delhasse (alison.delhasse@uliege.be)

The copyright of individual parts of the supplement might differ from the CC BY 4.0 License. 


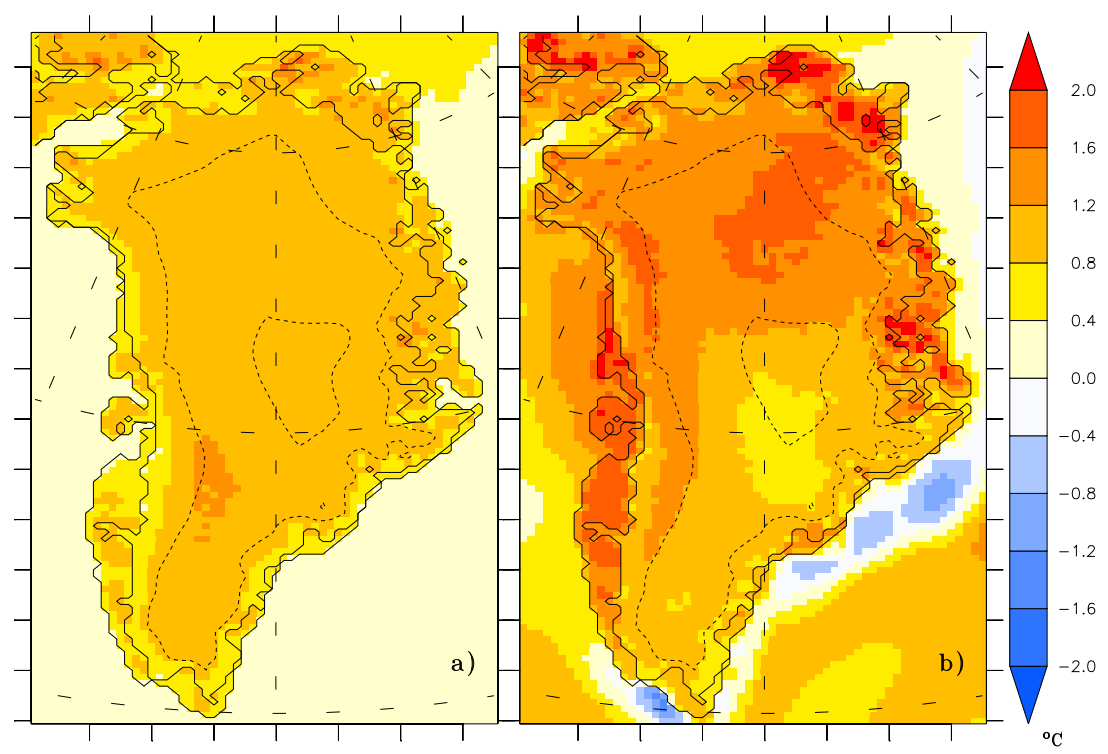

Figure S1. Mean anomalies of JJA near-surface temperature $\left({ }^{\circ} \mathrm{C}\right)$ of MAR forced by ERA-Interim warmer of $+1{ }^{\circ} \mathrm{C}$ over a) $1980-1999$ and b) 2000 - 2016 compared to MAR forced by unaltered ERA-Interim over 1980 - 1999. Dashed lines are equal altitude lines of $2000 \mathrm{~m}$ and $3000 \mathrm{~m}$. 


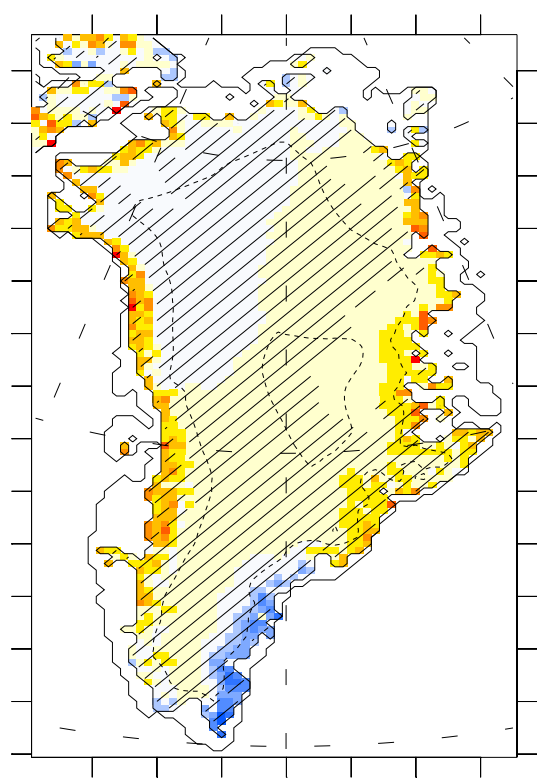

a) MARera+1 - MARcan+1

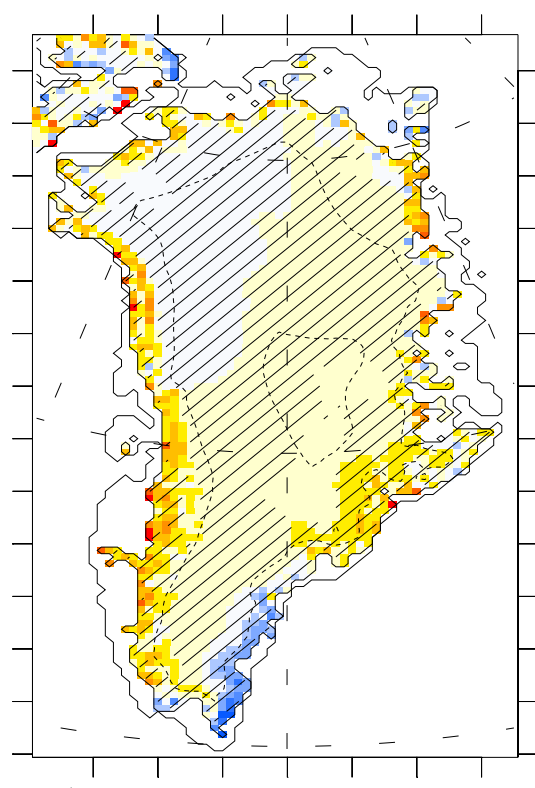

b) MARera +1.5 - MARcan +1.5

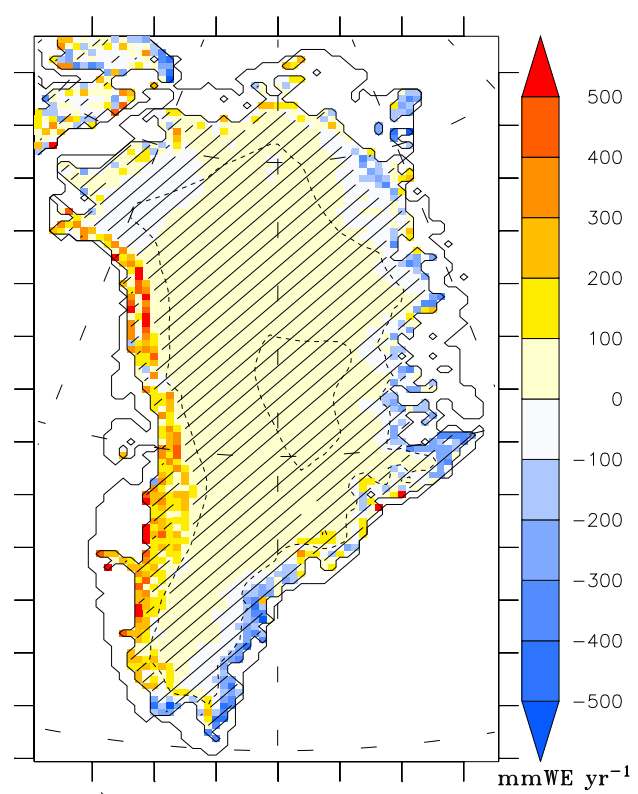

c) MARera+2 - MARcan+2

Figure S2. Differences of mean anomalies of annual SMB (in mmWE $y^{-1}$ ) between a) MARera+1 and MARcan+1, b) MARera+1.5 and MARcan+1.5 and c) MARera+2 and MARcan+2. Areas where anomaly differences are smaller than the inter-annual variability (i.e. the standard deviation) of the simulation of MAR forced by unaltered ERA-Interim over 1980 - 1999 are hatched. Dashed lines are equal altitude lines of $2000 \mathrm{~m}$ and $3000 \mathrm{~m}$. See Table S1 and Table S2 for abbreviations.

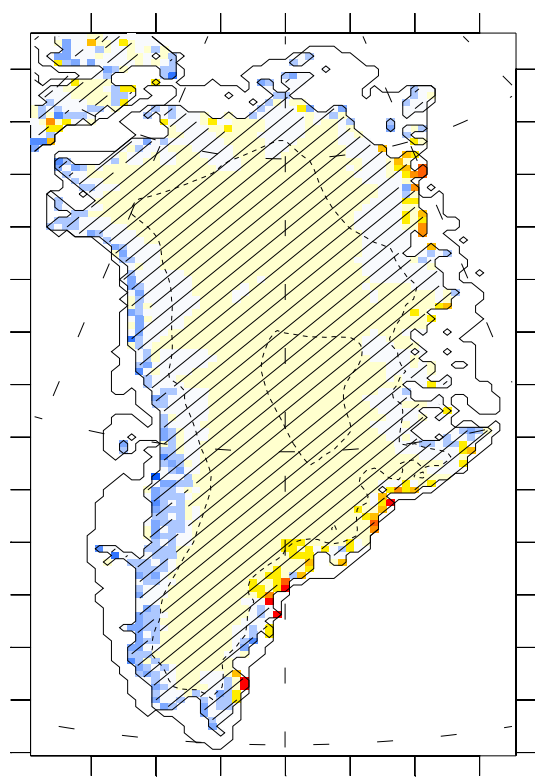

a) MARera+1 - MARnor+1

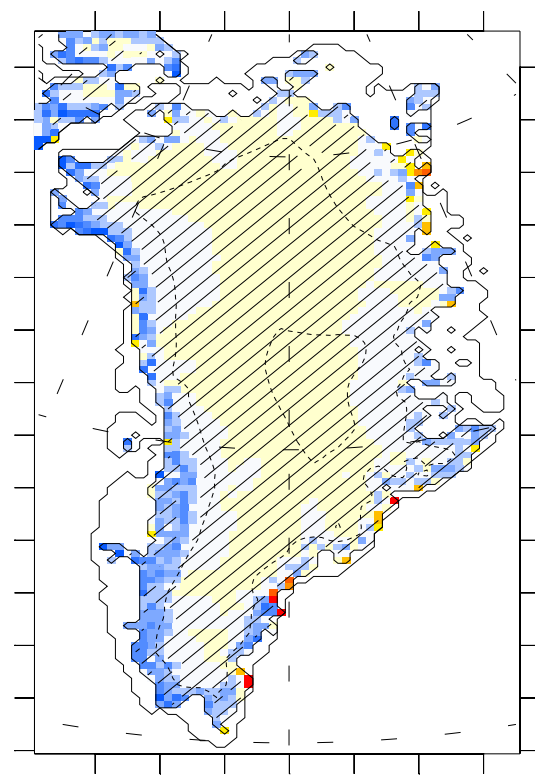

b) MARera+1.5 - MARnor +1.5

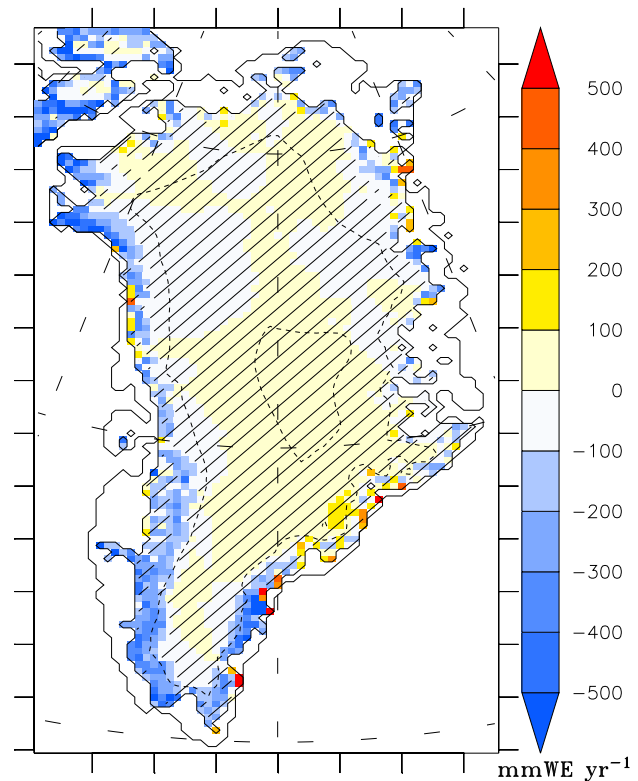

c) MARera+2 - MARnor +2

Figure S3. Same as Fig. S2 but for MARnor+x where x equals 1,1.5 or 2 . 


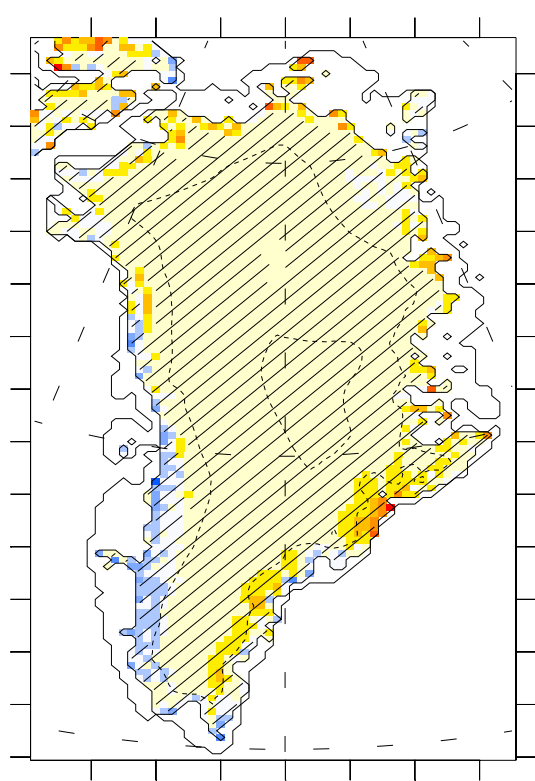

a) MARera+1 - MARmir +1

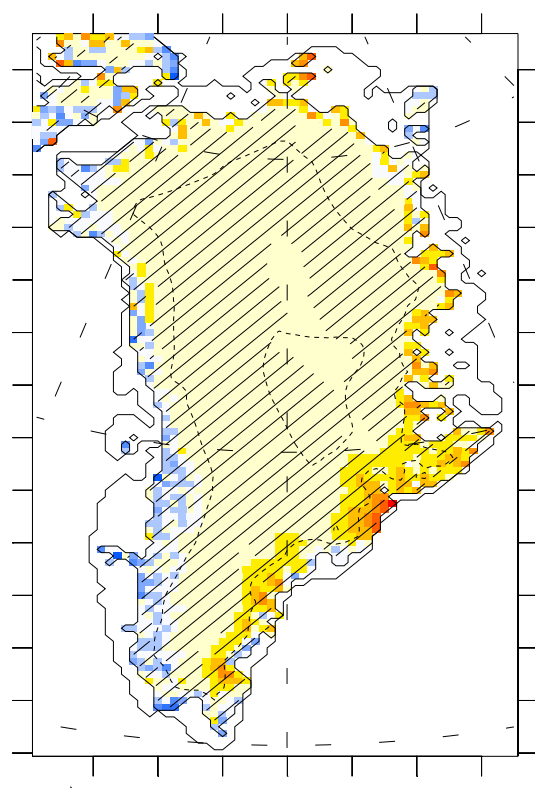

b) MARera+1.5 - MARmir+1.5

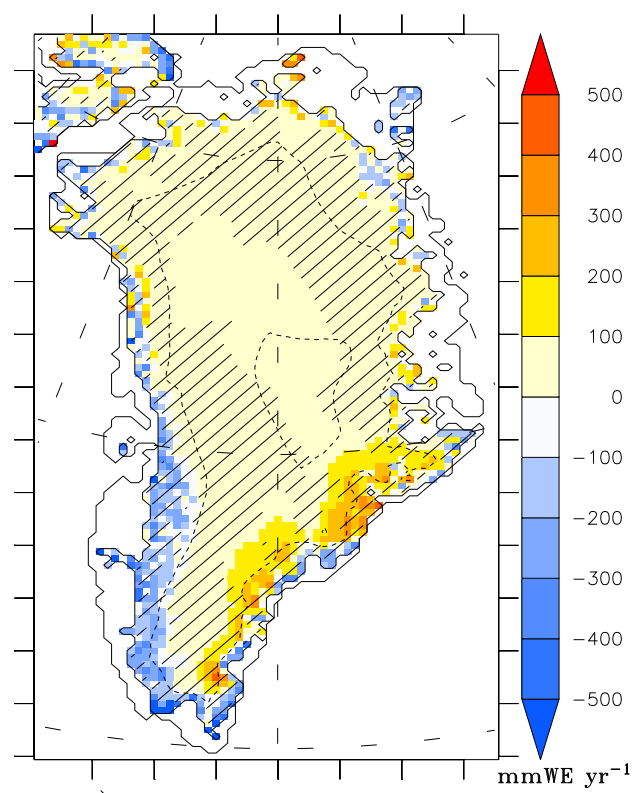

c) MARera +2 - MARmir +2

Figure S4. Same as Fig. S2 but for MARmir+x where x equals 1,1.5 or 2.

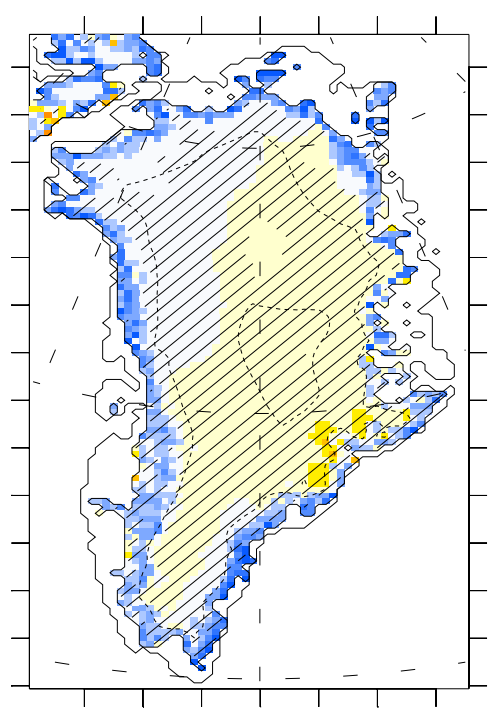

a) MARera $2 \mathrm{k}+1$ - MARcan +1.5

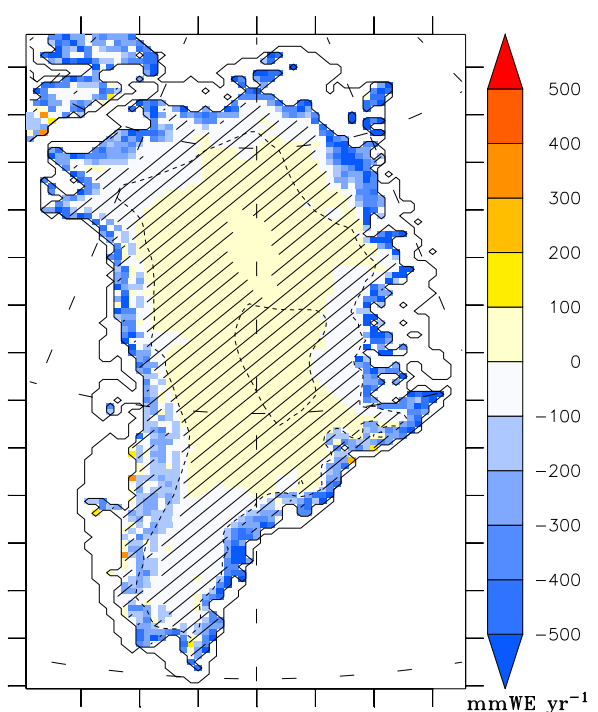

b) MARera2k+1.5 - MARcan +2

Figure S5. Differences of mean anomalies of annual SMB (in mmWE $y^{-1}$ ) between a) MARera2K+1 and MARcan+1.5 and b) MARera2K+1.5 and MARcan+2. Areas where anomaly differences are smaller than the inter-annual variability (i.e. the standard deviation) of the simulation of MAR forced by unaltered ERA-Interim over 1980 - 1999 are hatched. Dashed lines are equal altitude lines of $2000 \mathrm{~m}$ and $3000 \mathrm{~m}$. See Table S1 and Table S2 for abbreviations. 


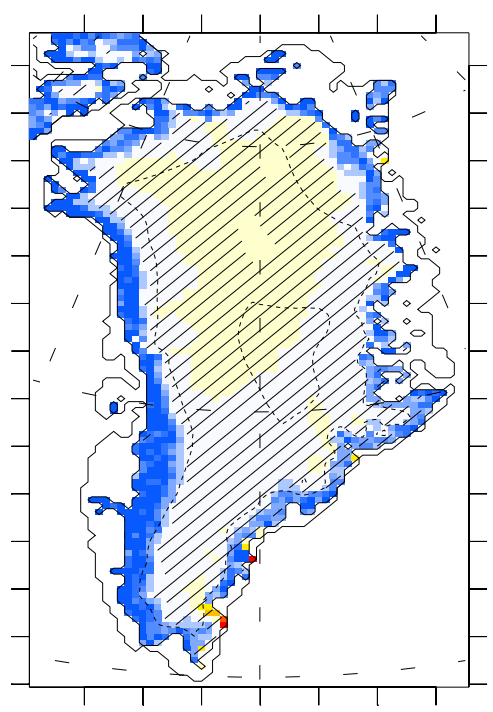

a) MARera2k +1 - MARnor+1.5

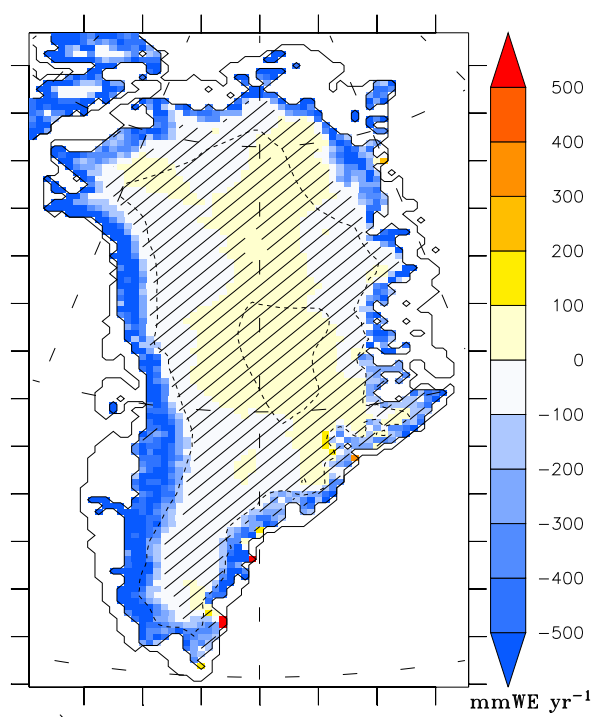

b) MARera2k+1.5 - MARnor+2

Figure S6. Same as Fig. S5 but for MARnor+x where x equals 1.5 or 2.

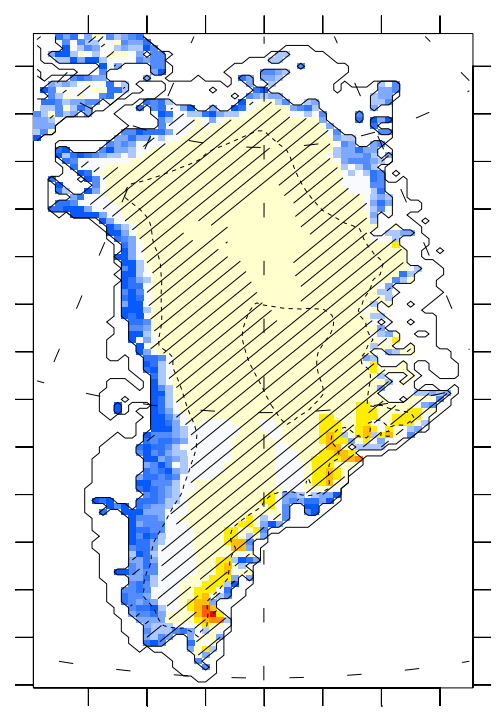

a) MARera2k +1 - MARmir+1.5

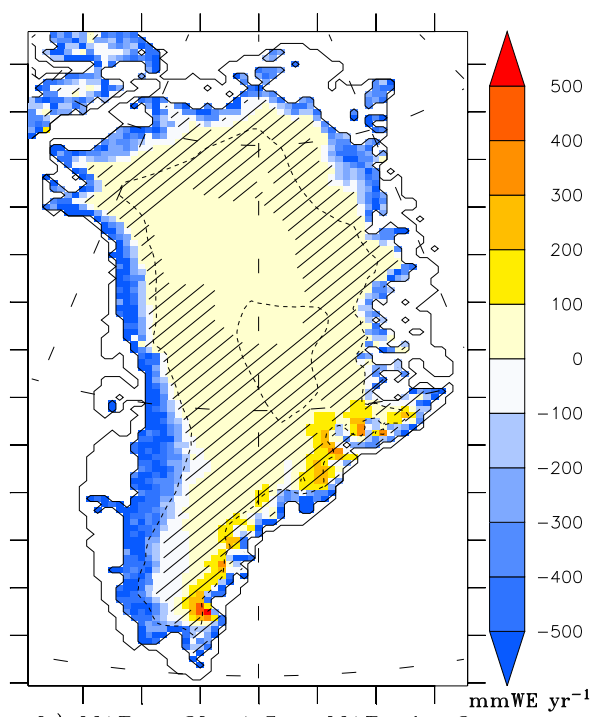

b) MARera2k+1.5 - MARmir+2

Figure S7. Same as Fig. S5 but for MARmir+x where x equals 1.5 or 2. 
Table S1. Abbreviation description of reanalysis sensitivity experiments

\begin{tabular}{ll}
\hline MARera+1 & $\begin{array}{l}\text { Anomalies between MAR forced by the ERA-Interim reanalysis warmer of }+1{ }^{\circ} \mathrm{C} \text { over } 1980-1999 \text { and } \\
\text { MAR forced by the unaltered ERA-Interim reanalysis over } 1980-1999\end{array}$ \\
\hline MARera+1.5 & $\begin{array}{l}\text { Anomalies between MAR forced by the ERA-Interim reanalysis warmer of }+1.5^{\circ} \mathrm{C} \text { over } 1980-1999 \text { and } \\
\text { MAR forced by the unaltered ERA-Interim reanalysis over } 1980-1999\end{array}$ \\
\hline MARera+2 & $\begin{array}{l}\text { Anomalies between MAR forced by the ERA-Interim reanalysis warmer of }+2{ }^{\circ} \mathrm{C} \text { over } 1980-1999 \text { and } \\
\text { MAR forced by the unaltered ERA-Interim reanalysis over } 1980-1999\end{array}$ \\
\hline AnRera2k & $\begin{array}{l}\text { Analtered ERA-Interim reanalysis over } 1980-1999 \\
\text { Anomalies between MAR forced by the ERA-Interim reanalysis warmer of }+1{ }^{\circ} \mathrm{C} \text { over } 2000-2016 \text { and } \\
\text { MAR forced by the unaltered ERA-Interim reanalysis over } 1980-1999\end{array}$ \\
\hline MARera2k+1.5 & $\begin{array}{l}\text { Anomalies between MAR forced by the ERA-Interim reanalysis warmer of }+1.5{ }^{\circ} \mathrm{C} \text { over } 2000-2016 \text { and } \\
\text { MAR forced by the unaltered ERA-Interim reanalysis over } 1980-1999\end{array}$ \\
\hline MARera2k+2 & $\begin{array}{l}\text { Anomalies between MAR forced by the ERA-Interim reanalysis warmer of }+2{ }^{\circ} \mathrm{C} \text { over } 2000-2016 \text { and } \\
\text { MAR forced by the unaltered ERA-Interim reanalysis over } 1980-1999\end{array}$ \\
\hline
\end{tabular}


Table S2. Abbreviation description of GCM sensitivity experiments

\begin{tabular}{|c|c|}
\hline MARmir+1 & $\begin{array}{l}\text { Anomalies between MAR forced by MIROC5 over a warmer } 20 \text {-yr period of }+1{ }^{\circ} \mathrm{C} \text { relative to the reference } \\
\text { period } 1980 \text { - } 1999 \text { and MAR forced by MIROC5 over the reference period }\end{array}$ \\
\hline MARmir+1.5 & $\begin{array}{l}\text { Anomalies between MAR forced by MIROC5 over a warmer } 20 \text {-yr period of }+1.5{ }^{\circ} \mathrm{C} \text { relative to the reference } \\
\text { period } 1980 \text { - } 1999 \text { and MAR forced by MIROC5 over the reference period }\end{array}$ \\
\hline MARmir+2 & $\begin{array}{l}\text { Anomalies between MAR forced by MIROC5 over a warmer } 20 \text {-yr period of }+2{ }^{\circ} \mathrm{C} \text { relative to the reference } \\
\text { period } 1980 \text { - } 1999 \text { and MAR forced by MIROC5 over the reference period }\end{array}$ \\
\hline MARnor+1 & $\begin{array}{l}\text { Anomalies between MAR forced by NorESM1 over a warmer } 20 \text {-yr period of }+1^{\circ} \mathrm{C} \text { relative to the reference } \\
\text { period } 1980 \text { - } 1999 \text { and MAR forced by MIROC5 over the reference period }\end{array}$ \\
\hline MARnor+1.5 & $\begin{array}{l}\text { Anomalies between MAR forced by NorESM1 over a warmer } 20 \text {-yr period of }+1.5{ }^{\circ} \mathrm{C} \text { relative to the reference } \\
\text { period } 1980-1999 \text { and MAR forced by MIROC5 over the reference period }\end{array}$ \\
\hline MARnor+2 & $\begin{array}{l}\text { Anomalies between MAR forced by NorESM1 over a warmer } 20 \text {-yr period of }+2{ }^{\circ} \mathrm{C} \text { relative to the reference } \\
\text { period } 1980 \text { - } 1999 \text { and MAR forced by MIROC } 5 \text { over the reference period }\end{array}$ \\
\hline MARcan+1 & $\begin{array}{l}\text { Anomalies between MAR forced by CanESM2 over a warmer } 20 \text {-yr period of }+1{ }^{\circ} \mathrm{C} \text { relative to the reference } \\
\text { period } 1980-1999 \text { and MAR forced by MIROC5 over the reference period }\end{array}$ \\
\hline MARcan+1.5 & $\begin{array}{l}\text { Anomalies between MAR forced by CanESM2 over a warmer } 20 \text {-yr period of }+1.5^{\circ} \mathrm{C} \text { relative to the reference } \\
\text { period } 1980-1999 \text { and MAR forced by MIROC5 over the reference period }\end{array}$ \\
\hline MARcan+2 & $\begin{array}{l}\text { Anomalies between MAR forced by CanESM2 over a warmer } 20 \text {-yr period of }+2{ }^{\circ} \mathrm{C} \text { relative to the reference } \\
\text { period } 1980 \text { - } 1999 \text { and MAR forced by MIROC } 5 \text { over the reference period }\end{array}$ \\
\hline
\end{tabular}

